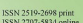

НАУКОВИЙ ВІСНИК

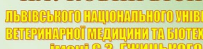

Scientific mesesenger of Lviv National University of
Veterinary Medicine end

indention

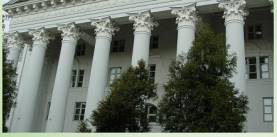

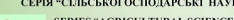

Том 23 № 94

2021
Науковий вісник Дьвівського національного університету ветеринарної медицини та біотехнодогій імені С.3. Гжицького. Серія: Сільськогосподарські науки

\section{Scientific Messenger of Lviv National University} of Veterinary Medicine and Biotechnologies. Series: Agricultural sciences doi: $10.32718 /$ nvlvet-a9416 https://nvlvet.com.ua/index.php/agriculture

UDC 636.4.084.1/087.8

\title{
Digestibility of substances, balance of Nitrogen, Zinc and Manganese in highly productive cows of the Holstein breed of German selection in the first period of lactation for feeding mixed ligand complexes of Zinc, Manganese and Cobalt
}

\author{
Yu. G. Kropyvka1, V. S. Bomko² \\ ${ }^{1}$ Stepan Gzhytskyi National University of Veterinary Medicine and Biotechnologies, Lviv, Ukraine \\ ${ }^{2}$ Bila Tserkva National Agrarian University, Bila Tserkva, Kyiv region, Ukraine
}

Article info

Received 19.02.2021

Received in revised form 18.03 .2021

Accepted 19.03.2021

Stepan Gzhytskyi National University of Veterinary Medicine and Biotechnologies Lviv, Pekarska Str., 50, Lviv,

79010, Ukraine.

Tel.: +38-097-431-88-30

E-mail:sy-kropuvka@ukr.net

Bila Tserkva National Agrarian University, pl. 8/1 Soborna Bila Tserkva, 09117, Ukraine.

Kropyvka, Yu. G., \& Bomko, V. S. (2021). Digestibility of substances, balance of Nitrogen, Zinc and Manganese in highly productive cows of the Holstein breed of German selection in the first period of lactation for feeding mixed ligand complexes of Zinc, Manganese and Cobalt. Scientific Messenger of Lviv National University of Veterinary Medicine and Biotechnologies. Series: Agricultural sciences, 23(94), 86-92. doi: 10.32718/nvlvet-a9416

The article deals with the results of research to study the digestibility of nutrients in the ration and metabolism of Nitrogen, Zinc and Manganese in high-yielding Holstein cows of German selection in the first period of lactation for feeding mixed ligand complexes of Zinc, Manganese and Cobalt. The research was performed in the conditions of Terezyne Ltd., Bila Tserkva district, Kyiv region. There was an increase in the coefficients of digestibility of dry matter in cows of the 2nd-5th experimental groups compared with animals of the $1^{\text {st }}$ control group, respectively by $1.8-3.5 \%(P<0.05)$; organic matter by $0.3-2.5 \%$; crude protein by $0.5-4.2 \%(P<0.05-P<0.01)$; crude fat by $1.1-1.8 \%$; crude fiber by $1.3-3.3 \%$ and nitrogenfree extractives by 2.1-4.2\%. Cows of the experimental groups consumed more Nitrogen than the cows of the control group: $20.18 \mathrm{~g}$ or $2.4 \%$ - the $2^{\text {nd }}$ group, $55.06 \mathrm{~g}$ or $6.6 \%$ - the $3^{\text {rd }}, 42.52 \mathrm{~g}$ or $5,1 \%-4^{\text {th }}$ and $28.98 \mathrm{~g}$ or $3.5 \%-5^{\text {th }}$ experimental group due to better eating of the feed mixture. General consumption level of Nitrogen in relation to excreted with milk and deposited in the body of cows of the control group was $32.02 \%$, and in animals of the $2^{\text {nd }}, 3^{\text {rd }}, 4^{\text {th }}$ and $5^{\text {th }}$ experimental groups $-33.59 \%$; 37.31; 36.99 and $34.97 \%$. In relation to the total digested amount, the proportion of Nitrogen deposited in the body and excreted with milk in animals of the control group was $42.38 \%$, and in the experimental - 44.25-47.34\%. Doses of Zinc, which provided its existing rate of 54-85\% due to the mixed ligand complex, positively influenced on the the metabolism of trace elements in the organism of experimental cows. Assimilation of Zinc in the organism was determined by the amount of its secretions with milk and deposits in the body and in absolute terms it was the lowest in cows of the $4^{\text {th }}$ and $5^{\text {th }}$ experimental groups $-562.7 \mathrm{mg}$ and $671.6 \mathrm{mg}$ against $740.8 \mathrm{mg}$ in the $1^{\text {st }}$ control group and the largest $-784.7 \mathrm{mg}$ and $801.3 \mathrm{mg}$ in animals of the $2^{\text {nd }}$ and $3^{\text {rd }}$ experimental groups. The use of a mixed ligand complex of manganese ensured its positive balance in the organism of cows and the absorption of the trace element in the organism of experimental cows ranged from $22.5 \%$ in the $2^{\text {nd }}$ experimental group to $33.2 \%$ in the $3^{\text {rd }}$ experimental group. The best indicators for the metabolism of Nitrogen, Zinc and Manganese were got in the third experimental group whose cows were fed a feed mixture, that in $1 \mathrm{~kg}$ of DM contained, mg: Zinc - 54.7; Manganese - 54.7; Cobalt-0.7; Selenium-0.3; Copper - 12 and Iodine - 1.1.

Key words: highly productive cows, digestibility, balance of Nitrogen, Zinc, Manganese, mixed ligand complex.

Перетравність речовин, баланс Нітрогену, Цинку і Мангану у високопродуктивних корів голштинської породи німецької селекції в перший період лактації за згодовування змішанолігандних комплексів Цинку, Мангану та Кобальту 


\section{Ю. Г. Кропивка ${ }^{1}$, В. С. Бомко ${ }^{2}$}

${ }^{1}$ Львівський національний університет ветеринарної медицини та біотехнологій імені С. 3. Гюсицького, м. Львів, Україна

${ }^{2}$ Білочерківський національний аграрний університет, м. Біла Церква, Україна

У статті наведені результати досліджень перетравності поживних речовин раціону та обміну Нітрогену, Цинку і Мангану у високопродуктивних корів голитинської породи німецької селекції в перший період лактації за згодовування змішанолігандних комплексів Цинку, Мангану та Кобальту. Дослідження проводилися в умовах ТОВ “Терезине” Білоиерківського району Київської області. Спостерігалося підвищення коефіцієнтів перетравності сухої речовини в корів 2-ї-5-ї дослідних груп порівняно з тваринами 1-ї контрольної групи відповідно на 1,8-3,5\% (P<0,05); органічної речовини на 0,3-2,5 \%; сирого протеїну на 0,54,2\% (P < 0,05-0,01); сирого жиру на 1,1-1,8\%; сирої клітковини на 1,3-3,3 \% $і$ безазотистих екстрактивних речовин на 2,14,2\%. Корови дослідних груп споживали більше Нітрогену від корів контрольної групи: на 20,18 г, або 2,4 \% - 2-ї групи, на 55,06 г, або 6,6 \% - 3-ї, на 42,52 г, або 5,1 \% - 4-ї й на 28,98 г, або 3,5\% - 5-ї дослідної групи за рахунок крашого поӥдання кормосуміші. Загальноспожитий рівень Нітрогену стосовно виділеного з молоком та відкладеного в тілі у корів контрольної групи становив 32,02 \%, а в тварин 2-ї, 3-ї, 4-ї і 5-ї дослідних груп - 33,59 \%; 37,31; 36,99 і 34,97 \%. По відношенню шзодо загальної перетравленої кількості частка Нітрогену, відкладеного в тілі й виділеного з молоком у тварин контрольної групи, становила 42,38 \%, а в дослідних - 44,25-47,34\%. Дози Цинку, які забезпечували існуючу його норму на 54-85 \% за рахунок змішанолігандного комплексу, позитивно вплинули на обмін мікроелементу в організмі піддослідних корів. Засвоєння Цинку в організмі визначали за кількістю його виділень з молоком і відкладенням у тілі $і$ за абсолютним значенням воно було найнижчим у корів 4-ї $i$ 5-ї дослідних груп - 562,7 мг $i$ 671,6 мг проти 740,8 мг у 1-й контрольній групі та найбільшим - 784,7 мг i 801,3 мг у тварин 2-ї і 3-ї дослідних груп. Використання змішанолігандного комплексу Мангану забезпечило позитивний його баланс в організмі корів $і$ засвоєння мікроелементу в організмі піддослідних корів коливалось від 22,5 \% в 2-й дослідній групі до 33,2\% в 3-й дослідній групі. Найкращі показники щзодо обміну Нітрогену, Цинку і Мангану одержано в третій дослідній групі, коровам якої згодовували кормосуміш, шзо в 1 кг СР містила, мг: Цинку - 54,7; Мангану - 54,7; Кобальту - 0,7; Селену - 0,3; Купруму - 12 і Йоду - 1,1.

Ключові слова: високопродуктивні корови, перетравність, баланс Нітрогену, Цинку, Мангану, зміманолігандний комплекс.

\section{Вступ}

В останні роки зарубіжний і вітчизняний досвід використання голштинської породи як поліпшуючої свідчить про ефективність проведеної селекційноплемінної роботи з розведення нових генотипів молочної худоби, які адаптовані до добрих умов експлуатації на фермах і комплексах. Проте в умовах, несприятливих для голштинської породи, зі збільшенням породності за голштинською породою, знижується тривалість господарського використання корів, що негативно позначається на рентабельності виробництва молока. Тому багаторічне використання корів $є$ особливо важливим у селекційній роботі, оскільки пов'язане 3 темпами ремонту стада, а отже й з інтенсивністю добору. Передчасне вибракування корів не лише скорочує племінні ресурси порід, а й завдає економічної шкоди галузі загалом, оскільки витрати на вирощування високопродуктивних корів починають окуплюватися тільки після третього отелення. Саме тому важливим є комплекс заходів щодо збільшення тривалості продуктивного використання корів (Siratskyi et al., 2008; Grashin \& Grashin, 2012; Loretts, 2014; Usenko \& Bayurov, 2014; Grymak et al., 2020; Borshch et al., 2020; Mazur et al., 2020; Roman et al., 2020).

Донедавна традиційними джерелами мікроелементів у годівлі сільськогосподарських тварин були мінеральні солі у вигляді сульфатних і хлоридних сполук, однак метали 3 цих сполук у шлунково-кишковому каналі легко трансформуються в гідрооксисистеми 3 низькою біодоступністю, а також проявляють один до одного антагоністичну дію й негативно впливають на організм тварин. Тому навіть достатня кількість неорганічних солей Цинку, Мангану, Кобальту та Селену в раціоні може призвести до їхнього дефіциту, оскільки організм тварин адаптований до засвоєння органічних хелатних форм мінералів, які містяться в структурі рослин. Низька засвоюваність неорганічних мінералів підвищує ризик забруднення навколишнього середовища, оскільки вони більшою мірою виділяються 3 організму, ніж всмоктуються. При цьому кристалізована вода, яка міститься в молекулах сульфатів, може руйнувати сам метал та вітаміни в преміксах.

У зв'язку з цим краще в раціонах високопродуктивних корів використовувати хелати, які впливають на інтенсивність розвитку мікрофлори. Таким чином, підвищується ефективність всього процесу перетравлення й ферментації кормів у травному тракті. Отже, хелатні форми металів гарантують підвищення доступності корму для бактерій.

3 мікроелементів важливу роль у підвищені біологічної повноцінності годівлі тварин відіграє балансування раціонів за вмістом Цинку, Мангану, Кобальту, Купруму, Йоду та інших (Sudakov et al., 1991; Lonnerdal, 2000; Klitsenko et al., 2001; Ibatullin \& Holubiev, 2017), тому що життєдіяльність, рівень обмінних процесів, резистентність, продуктивність, відтворна здатність високопродуктивних корів залежать від їхнього вмісту в їх організмі.

Основним джерелом вищеназваних мікроелементів для тварин $є$ корми. Практичний досвід ведення скотарства сучасних молочних комплексів України свідчить про те, що корми, які вводяться до складу раціонів, не завжди задовольняють потребу високопродуктивних корів в мікроелементах (Vinogradov, 1952; Mahan, 1990; Kuznecov, 1992; Stoljarchuk et al., 2000).

Тому метою роботи було вивчення ефективності використання різних рівнів змішанолігандних комплексів Цинку, Мангану й Кобальту в годівлі високопродуктивних корів голштинської породи німецької селекції та їх впливу на перетравність поживних речовин та баланс Нітрогену, Цинку і Мангану в перший період лактації. 


\section{Матеріал і методи досліджень}

Корів для досліду в ТОВ “Терезине” Білоцерківського району Київської області відбирали в кінці першої лактації за принципом аналогів 3 врахуванням віку, походженням, дати плодотворного осіменіння, живої маси й молочної продуктивності. Усі відібрані корови-аналоги були чистопородні, мали схожу продуктивність матерів, середню вгодованість та були клінічно здоровими, утримувались в однакових умовах і одночасно були завезені нетелями в господарство з Німеччини. Корів було розділено на п'ять груп: одну контрольну і чотири дослідні. Контролем слу- жила оптимальна доза змішанолігандних комплексів Цинку, Мангану й Кобальту, яка була встановлена в попередньому досліді (Kropyvka \& Bomko, 2017; Bomko, 2020) з концентрацією в 1 кг сухої речовини (СР) кормосуміші (КС), мг: Цинку - 60,8; Мангану 60,8 і Кобальту - 0,78. Для 2-ї дослідної групи концентрацію цих мікроелементів збільшили на 10 \%, а в 3й - навпаки, зменшили на цю кількість. Стосовно 4-ї і 5-ї дослідних груп, то концентрацію в 1 кг СР кормосуміші Цинку, Мангану й Кобальту зменшили на 20 i 30 \% відповідно порівняно $з$ контролем. Схема досліду наведена в таблиці 1.

Таблиця 1

Схема науково-господарського досліду, $\mathrm{n}=10$

\begin{tabular}{|c|c|}
\hline Група & Досліджуваний фактор \\
\hline 1 контрольна & $\begin{array}{l}\text { КС + змішанолігандні комплекси Цинку, Мангану, Кобальту + Суплекс Se й сульфат купруму та йодит } \\
\text { калію. В } 1 \text { кг СР міститься, мг: Цинку - 60,8; Мангану - 60,8; Кобальту - 0,78; Селену - 0,3; Купруму - } \\
12 \text { і Йоду - } 1,1\end{array}$ \\
\hline 2 дослідна & $\begin{array}{l}\text { КС + змішанолігандні комплекси Цинку, Мангану, Кобальту + Суплекс Se й сульфат купруму та йодит } \\
\text { калію. В } 1 \text { кг СР міститься, мг: Цинку - 66,9; Мангану - 66,9; Кобальту }-0,86 \text {; Селену - 0,3; Купруму - } \\
12 \text { і Йоду - } 1,1\end{array}$ \\
\hline 3 дослідна & $\begin{array}{l}\text { КС + змішанолігандні комплекси Цинку, Мангану, Кобальту + Суплекс Se й сульфат купруму та йодит } \\
\text { калію. В } 1 \text { кг СР міститься, мг: Цинку - 54,7; Мангану - 54,7; Кобальту - 0,7; Селену }-0,3 ; \text { Купруму - } 12 \\
\text { і Йоду - } 1,1\end{array}$ \\
\hline 4 дослідна & $\begin{array}{l}\text { КС + змішанолігандні комплекси Цинку, Мангану, Кобальту + Суплекс Se й сульфат купруму та йодит } \\
\text { калію. В } 1 \text { кг СР міститься, мг: Цинку - 48,6; Мангану }-48,6 \text {; Кобальту }-0,62 ; \text {;елену }-0,3 \text {; Купруму }- \\
12 \text { і Йоду }-1,1\end{array}$ \\
\hline 5 дослідна & $\begin{array}{l}\text { КС + змішанолігандні комплекси Цинку, Мангану, Кобальту + Суплекс Se й сульфат купруму та йодит } \\
\text { калію. В } 1 \text { кг СР міститься, мг: Цинку - 42,6; Мангану - 42,6; Кобальту - 0,55; Селену - 0,3; Купруму - } \\
12 \text { і Йоду }-1,1\end{array}$ \\
\hline
\end{tabular}

Піддослідних корів у підготовчий період, який збігався з сухостійним періодом, годували малокомпонентними кормосумішками, до складу яких уводили: сіно вико-вівсяне - 4 кг, сінаж злаково-бобовий 10 кг, силос кукурудзяний - 25 кг, мелясу - 2 кг, комбікорм-концентрат - 3,5 кг, сіль кухонну - 0,19 кг, знефторений фосфат - 0,18 кг. Після розтелу піддослідним лактуючим коровам поступово сіно виковівсяне замінили на люцернове й у кормосуміші збільшували кормову даванку концентрованих кормів, які також згодовували у вигляді комбікормуконцентрату.

Отримувані тваринами корми як у сухостійний, так і в період лактації були дефіцитними на Цинк, Купрум, Кобальт, Манган, Йод та Селен. Для покриття дефіциту у вищевказаних мікроелементах для корів контрольної і дослідних груп уводили в комбікормиконцентрати премікс з різними дозами змішанолігандних комплексів Цинку, Мангану й Кобальту. Дефіцит Купруму покривали за рахунок його сульфату, а дефіцит у Селені - за рахунок Суплексу Селену, 3 розрахунку 0,3 мг/кг сухої речовини.

\section{Результати та їх обговорення}

Висока ефективність використання кормів коровами у період роздою певною мірою залежить від перетравності поживних речовин, на яку впливає ціла низка чинників. Серед них найвагомішу роль відіграє набір кормів у раціоні та його структура, а також повноцінність і збалансованість годівлі тварин. Дані про вплив різних доз змішанолігандних комплексів Цинку, Мангану й Кобальту в кормосуміші корів голштинської породи німецької селекції в період перших 100 днів лактації на показники перетравності поживних речовин, наведені у таблиці 2.

Як показали результати досліджень (табл. 2), перетравність поживних речовин була на високому рівні в корів усіх дослідних груп. Проте мали місце й міжгрупові відмінності. Зокрема, спостерігалося підвищення коефіцієнтів перетравності сухої речовини в корів 2-ї-5-ї дослідних груп порівняно з тваринами 1-ї контрольної групи відповідно на 1,8-3,5 \% (P $<0,05)$; органічної речовини на $0,3-2,5 \%$; сирого протеїну на $0,5-4,2 \%$ (P $<0,05-0,01)$; сирого жиру на 1,1-1,8 \%; сирої клітковини на 1,3-3,3 \% і безазотистих екстрактивних речовин на 2,1-4,2 \%. Отже, встановлено позитивний вплив згодовування різних рівнів змішанолігандних комплексів Цинку, Мангану й Кобальту на перетравність поживних речовин у корів голштинської породи німецької селекції в перші 100 днів лактації.

Білки в організмі відіграють провідну роль, оскільки виконують найрізноманітніші функції, тому про характер впливу змішанолігандних комплексів Цинку, Мангану й Кобальту на організм піддослідних корів робили висновок за балансом Нітрогену, дані про що наведені в таблиці 3. 
Таблиця 2

Перетравність поживних речовин раціонів, \% $(\mathrm{M} \pm \mathrm{m}, \mathrm{n}=3)$

\begin{tabular}{lccccc}
\hline \multirow{2}{*}{\multicolumn{1}{c}{ Показники }} & \multicolumn{5}{c}{ Групи тварин } \\
\cline { 2 - 6 } & \multicolumn{2}{c}{ контрольна } & \multicolumn{3}{c}{ дослідні } \\
\cline { 2 - 6 } & 1 & 2 & 3 & 4 & $77,8 \pm 1,91$ \\
Суха речовина & $74,7 \pm 1,78$ & $76,5 \pm 2,41$ & $78,2 \pm 1,93 *$ & $76,8 \pm 0,98$ & $82,2 \pm 2,16$ \\
Органічна речовина & $80,2 \pm 1,57$ & $80,5 \pm 1,68$ & $82,7 \pm 2,32$ & $81,3 \pm 2,05$ & $76,5 \pm 1,22 *$ \\
Сирий протеїн & $73,4 \pm 1,77$ & $73,9 \pm 1,54$ & $77,6 \pm 1,37 * *$ & $74,7 \pm 1,72$ & $69,3 \pm 2,38$ \\
Сирий жир & $67,9 \pm 2,17$ & $69,0 \pm 1,94$ & $69,7 \pm 2,11$ & $69,2 \pm 2,09$ & $62,9 \pm 0,85$ \\
Сира клітковина & $60,5 \pm 0,84$ & $61,8 \pm 0,67$ & $63,8 \pm 0,79$ & $63,5 \pm 0,76$ & $89,3 \pm 2,43$ \\
БЕР & $85,5 \pm 0,97$ & $87,6 \pm 1,21$ & $89,7 \pm 2,23$ & $88,5 \pm 2,73$ &
\end{tabular}

Примітка: в цій таблиці й далі *** - $\mathrm{P}<0,001 ; * *-\mathrm{P}<0,01 ; *-\mathrm{P}<0,05$

Таблиця 3

Середньодобовий обмін Нітрогену в піддослідних корів, г $(\mathrm{n}=3)$

\begin{tabular}{|c|c|c|c|c|c|}
\hline \multirow{3}{*}{ Показники } & \multicolumn{5}{|c|}{ Групи тварин } \\
\hline & \multirow{2}{*}{$\begin{array}{c}\text { контрольна } \\
1 \\
\end{array}$} & \multicolumn{4}{|c|}{ дослідні } \\
\hline & & 2 & 3 & 4 & 5 \\
\hline Спожито з кормами & 828,32 & 848,48 & 883,36 & 870,84 & 857,28 \\
\hline Перетравлено & 617,10 & 644,00 & 696,09 & 681,88 & 654,10 \\
\hline Виділено з: калом & 211,22 & 204,48 & 187,27 & 197,96 & 203,18 \\
\hline сечею & 351,87 & 359,02 & 356,53 & 359,73 & 354,35 \\
\hline молоком & 254,43 & 273,68 & 295,96 & 279,75 & 287,55 \\
\hline всього & 817,52 & 837,18 & 839,76 & 828,44 & 845,08 \\
\hline Відкладено у тілі, $\mathrm{M} \pm$ m & $10,8 \pm 0,22$ & $11,3 \pm 0,29$ & $33,6 \pm 0,18 * * *$ & $42,4 \pm 0,24 * * *$ & $12,2 \pm 0,28^{*}$ \\
\hline Відкладено в тілі й молоці & 265,23 & 284,98 & 329,56 & 322,15 & 299,75 \\
\hline \% до перетравленого & 42,98 & 44,25 & 47,34 & 47,24 & 45,83 \\
\hline \% до спожитого & 32,02 & 33,59 & 37,31 & 36,99 & 34,97 \\
\hline
\end{tabular}

3 таблиці 3 видно, що піддослідні корови в середньому за добу споживали різну кількість Нітрогену. Корови дослідних груп споживали більше Нітрогену від корів контрольної групи: на 20,18 г або 2,4 \% - 2-ї групи, на 55,06 г або 6,6 \% - 3-ї, на 42,52 г або 5,1 \% - 4-ї й на 28,98 г або 3,5 \% - 5-ї дослідної групи за рахунок кращого поїдання кормосуміші. Так, корови контрольної групи споживали з кормосумішю 5175 г сирого протеїну за добу під час балансового досліду, а корови 2-ї, 3-ї, 4-ї і 5-ї дослідних груп відповідно 5303 г, 5521, 5499 і 5358 г. Виділення Нітрогену 3 калом у корів контрольної й дослідних груп було також неоднаковим. У корів 1-ї контрольної групи за добу виділялося 3 калом 211,22 г Нітрогену, а в корів 2-ї, 3-ї, 4-ї і 5-ї дослідних груп екскреція 3 калом була на 6,74 г, 23,95; 13,26 і 8,04 г меншою. За рахунок цього в дослідних корів порівняно 3 контролем частка перетравленого Нітрогену зросла щодо груп на 26,9 г; 78,99; 64,78 і 37,0 г.

Виділення Нітрогену 3 сечею вказує на ефективність використання перетравленого Нітрогену. У досліді кількість Нітрогену, яка виділялася з сечею у корів 2-ї дослідної групи, була меншою, ніж у контролі, на 7,15 г, або 2,0%. Що стосується корів 3-ї, 4-ї і 5-ї дослідних груп, то 3 їх сечею щодоби виділялося на 4,68 г; 7,86 і 2,48 г Нітрогену менше порівняно 3 контролем, що, очевидно, було зумовлено більшою кількістю перетравленого Нітрогену. Найкраще використовували Нітроген корови 3-ї дослідної групи.
Краща перетравність та менша екскреція Нітрогену 3 сечею сприяли збільшенню його трансформації в білок молока корів. При цьому корови 2-ї, 3-ї, 4-ї і 5-ї дослідних груп виділяли 3 молоком за добу порівняно з контролем на 19,25 г; 41,53; 25,32 і 33,12 г Нітрогену більше, що, мабуть, було одним із основних чинників підвищення їхньої молочної продуктивності.

Відкладання Нітрогену в тілі було більшим у корів дослідних груп, незважаючи на більш інтенсивне його використання на продукування молока. Корови 2-ї, 3-ї, 4-ї і 5-ї дослідних груп відкладали Нітрогену в тілі порівняно з контролем щодоби більше на 0,5 г; 22,8; 31,6 i 1,4 г. Загальне продуктивне використання Нітрогену на відкладення в тілі й синтез молока в корів дослідних груп було вищим за контроль на 19,75-64,33 г, або 7,45-24,25 \%. Про краще використання Нітрогену дослідними коровами свідчать відносні показники. Наприклад, якщо загальноспожитий рівень Нітрогену щодо виділеного 3 молоком та відкладеного в тілі у корів контрольної групи становив 32,02 \%, то в тварин 2-ї, 3-ї, 4-ї і 5-ї дослідних груп - 33,59\%; 37,31; 36,99 і 34,97 \%, а щодо загальної перетравленої кількості частка Нітрогену, відкладеного в тілі й виділеного з молоком у тварин контрольної групи, становила 42,38 \%, а в дослідних - 44,25-47,34\%.

Баланс Цинку в організмі лактуючих корів наведений у таблиці 4. 
Таблиця 4

Середньодобовий баланс Цинку в піддослідних корів, мг/гол. (n=3)

\begin{tabular}{|c|c|c|c|c|c|}
\hline \multirow{3}{*}{ Показники } & \multicolumn{5}{|c|}{ Групи тварин } \\
\hline & \multicolumn{2}{|l|}{ контрольна } & \multicolumn{2}{|c|}{ дослідні } & \\
\hline & 1 & 2 & 3 & 4 & 5 \\
\hline Спожито з кормами & 1684,2 & 1893,3 & 1651,9 & 1404,5 & 1167,2 \\
\hline Виділено, всього & 1138,5 & 1304,8 & 1062,2 & 933,6 & 799,6 \\
\hline у тому числі з: калом & 871,2 & 1033,3 & 778,6 & 660,0 & 543,5 \\
\hline сечею & 72,2 & 75,3 & 72,0 & 71,9 & 70,4 \\
\hline молоком & 195,1 & 196,2 & 211,6 & 200,7 & 185,1 \\
\hline Відкладено в тілі, $\mathrm{M} \pm \mathrm{m}$ & $545,7 \pm 16,3$ & $588,5 \pm 19,1$ & $589,7 \pm 9,3^{*}$ & $470,9 \pm 8,7^{* *}$ & $367,6 \pm 7,8^{* * *}$ \\
\hline У \% до спожитого & 32,4 & 31,1 & 35,7 & 33,5 & 31,5 \\
\hline Відкладено в тілі й молоці, $\mathrm{M} \pm \mathrm{m}$ & $740,8 \pm 18,4$ & $784,7 \pm 16,4$ & $801,3 \pm 17,9^{*}$ & $671,6 \pm 16,9^{*}$ & $562,7 \pm 18,3^{* *}$ \\
\hline У \% до спожитого & 44,0 & 41,5 & 48,5 & 47,8 & 47,3 \\
\hline
\end{tabular}

Як свідчать дані таблиці 4, дози Цинку, які забезпечували існуючу його норму на 54-85\% за рахунок змішанолігандного комплексу, позитивно вплинули на обмін мікроелементу в організмі піддослідних корів. Наприклад, використання в раціоні контрольних корів дози, яка була менше за норму на $20 \%$, привела до позитивного балансу Цинку, якого відклалось у тілі 545,7 мг/голову/добу, а в молоці - 195,7 мг/голову/добу, що склало 32,4 \% відкладеного в тілі до спожитого. У корів 2-ї дослідної групи, де доза Цинку була на 10 \% вище від контролю, його відкладено в тілі 588,5 мг/голову/добу, а в молоці - 196,2 мг/голову/добу, що склало на 42,8 мг більше в тілі і на 1,1 мг більше у молоці, ніж у контрольній групі. Менша доза Цинку (на 10 \% від контрольної групи) в раціоні тварин 3-ї дослідної групи зумовила зростання відкладення цього елемента в тілі до 589,7 мг/голову/добу проти 545,7 мг/голову/добу у корів контрольної групи, а в молоці - відповідно 211,6 проти 195,1 мг/голову/добу. У тварин 4-ї дослідної групи відкладання Цинку в тілі було ще меншим, на 118,8 мг/голову/добу порівняно 3 3-ю дослідною групою, а в 5-й групі, де доза була меншою на $30 \%$ за контрольну групу і на 20 \% за 3-ю дослідну групу, відкладання Цинку в тілі було ще меншим - на 178,1 мг/голову/добу за контрольну групу i на 222,1 мг/голову/добу за 3-ю дослідну групу.

Щодо засвоєння Цинку в організмі, яке визначали за кількістю його виділень 3 молоком і відкладенням у тілі, то за абсолютним значенням воно було найнижчим у корів 4-ї і 5-ї дослідних груп - 562,7 мг і 671,6 мг проти 740,8 мг у 1-й контрольній групі та найбільшим - 784,7 мг і 801,3 мг у тварин 2-ї і 3-ї дослідних груп. Проте, що стосується засвоєння Цинку стосовно спожитої його кількості, то воно було найвищим у корів 3-ї дослідної групи - 48,5 \%. Зі зменшенням дози Цинку у раціоні корів 4-ї та 5-ї дослідних груп засвоєння його в організмі було меншим за тварин 3-ї дослідної групи, але більшим, ніж у корів контрольної групи та складало 47,8 \% і 47,3\% відповідно. Найменшим було засвоєння Цинку від спожитого у 2-ій дослідній групі і становило $41,5 \%$

Проаналізувавши екскрецію Цинку 3 продуктами обміну корів, зазначимо, що найбільше Цинку виділялося 3 калом у корів 1-ї контрольної та 2-ї дослідної групи - 871,2 мг і 1033,3 мг. Те ж саме було характерним і для екскреторних виділень Цинку 3 сечею.

У корів контрольної групи, незважаючи на позитивний баланс, 3 молоком щодоби виділялося 1954,1 мг Цинку. Доза Цинку в раціоні корів 2-ї дослідної групи, яка на 10 \% була більшою за дозу для корів контрольної групи, зумовила збільшення кількості виділеного з молоком Цинку до 196,2 мг, що більше, ніж у контролі, на 1,1 мг. У середньодобовому надої молока корів 3-ї дослідної групи вміст Цинку складав 211,6 мг, що більше порівняно з контролем на 81,3 мг, або 35,3 \%, хоча доза Цинку в раціоні зменшилась на $15 \%$. У середньодобовому надої молока корів 4-ї дослідної групи вміст Цинку складав 282,3 мг, що більше порівняно 3 контролем на 51,8 мг, або 22,5 \%. I нарешті, $з$ молока у корів 5-ї дослідної групи щодоби виділялося 233,7 мг Цинку, що перевищувало контроль на 16,5 мг, або 8,5\%. Наведені дані свідчать про те, що зі зменшенням дози Цинку в раціоні адекватного зменшення його вмісту в молоці корів не відбувалося.

Під час балансових дослідів піддослідні корови споживали ті ж самі дози Мангану, що і під час досліду. У таблиці 5 наведені дані середньодобового балансу Мангану в піддослідних корів.

3 таблиці 5 видно, що використання змішанолігандного комплексу Мангану, концентрація якого в 1 кг СР становила, мг: 60,8 - контрольна група, 66,9 - 2-а дослідна, 54,7 - 3-я дослідна, 48,6 4-а дослідна і 42,6 - 5-а дослідна групи, забезпечує позитивний його баланс в організмі корів. Відкладання Мангану в тілі піддослідних корів коливалось від 318,4 мг/голову/добу в 5-й дослідній групі до 512,7 мг/голову/добу в 3-й дослідній групі. Найнижчий відсоток відкладання Мангану від спожитого $(21,0 \%)$ у 2-й дослідній групі, де була найбільша його доза в раціоні, пояснюється більшим його виділенням з організму та меншим споживанням кормової суміші. Найкраще споживали повнораціонну кормосуміш корови 3-ї дослідної групи, раціони яких на $70 \%$ забезпечували норму Мангану за рахунок змішанолігандного його комплексу. 
Таблиця 5

Середньодобовий баланс Мангану в піддослідних корів, мг/гол. $(\mathrm{n}=3)$

\begin{tabular}{|c|c|c|c|c|c|}
\hline \multirow{3}{*}{ Показники } & \multicolumn{5}{|c|}{ Групи тварин } \\
\hline & \multicolumn{2}{|l|}{ контрольна } & \multicolumn{3}{|c|}{ дослідні } \\
\hline & 1 & 2 & 3 & 4 & 5 \\
\hline Спожито з кормами & 1684,2 & 1893,3 & 1651,9 & 1404,5 & 1167,2 \\
\hline Виділено, всього & 1266,4 & 1497,7 & 1139,2 & 1022,0 & 848,8 \\
\hline у тому числі з: калом & 1235,6 & 1465,1 & 1102,2 & 989,7 & 820,5 \\
\hline сечею & 2,26 & 1,90 & 2,05 & 2,04 & 1,78 \\
\hline молоком & 28,5 & 30,7 & 35,0 & 30,3 & 26,5 \\
\hline Відкладено в тілі, $\mathrm{M} \pm \mathrm{m}$ & $417,8 \pm 12,6$ & $395,6 \pm 9,1$ & $512,7 \pm 10,3^{*}$ & $382,5 \pm 13,7^{* *}$ & $318,4 \pm 9,8 * * *$ \\
\hline У \% до спожитого & 24,8 & 21,0 & 31,0 & 27,2 & 27,0 \\
\hline Відкладено в тілі й молоці, $\mathrm{M} \pm \mathrm{m}$ & $446,3 \pm 13,4$ & $426,3 \pm 14,6$ & $547,7 \pm 10,9^{*}$ & $412,8 \pm 11,8^{*}$ & $343,9 \pm 10,3 * *$ \\
\hline У \% до спожитого & 26,5 & 22,5 & 33,2 & 29,4 & 29,5 \\
\hline
\end{tabular}

Засвоєння Мангану в організмі піддослідних корів коливалось від 22,5 \% в 2-й дослідній групі до 33,2 \% в 3-й дослідній групі. Стосовно 4-ї і 5-ї дослідних груп, то тут відкладання Мангану було більшим на 2,9-3,0 \% від контрольної групи при менших дозах надходження змішанолігандного його комплексу.

\section{Висновки}

Встановлено позитивний вплив згодовування різних рівнів змішанолігандних комплексів Цинку, Мангану й Кобальту на перетравність поживних речовин у корів голштинської породи німецької селекції в перші 100 днів лактації. Найкращі показники щодо обміну Нітрогену, Цинку і Мангану одержано в третій дослідній групі, коровам якої згодовували кормосуміш, що в 1 кг СР містила, мг: Цинку - 54,7; Мангану 54,7; Кобальту - 0,7; Селену - 0,3; Купруму - 12 і Йоду $-1,1$.

Перспективи подальших досліджень. В процесі подальших досліджень буде вивчено вплив різних рівнів змішанолігандних комплексів Цинку, Мангану і Кобальту на показники продуктивності корів української чорно-рябої молочної породи.

\section{References}

Bomko, V. S., Kropyvka, Yu. H., \& Bomko, L. H. (2020). Obmin Tsynku, Kobaltu i Selenu u vysokoproduktyvnykh koriv $\mathrm{v}$ pershi 100 dniv laktatsii za zghodovuvannia yim zmishanolihandnykh kompleksiv. Tavriiskyi naukovyi visnyk. 114, 156163. doi: 10.32851/2226-0099.2020.114.18 (in Ukrainian).

Borshch, O. O., Gutyj, B. V., Sobolev, O. I., Borshch, O. V., Ruban, S. Yu., Bilkevich, V. V., Dutka, V. R., Chernenko, O. M., Zhelavskyi, M. M., \& Nahirniak, T. (2020). Adaptation strategy of different cow genotypes to the voluntary milking system. Ukrainian Journal of Ecology, 10(1), 145-150. doi: 10.15421/2020_23.

Borshch, O. O., Ruban, S. Yu., Gutyj, B. V., Borshch, O. V., Sobolev, O. I., Kosior, L. T., Fedorchenko, M. M., Kirii, A. A., Pivtorak, Y. I., Salamakha, I. Yu., Hordiichuk, N. M., Hordiichuk, L. M., Kamratska, O. I., \& Denkovich, B. S. (2020). Comfort and cow behavior during periods of intense precipitation. Ukrain- ian Journal of Ecology, 10(6), 98-102. doi: 10.15421/2020_265.

Grashin, V. A., \& Grashin, A. A. (2012). Molochnaya produktivnost i prodolzhitelnost hozyaystvennogo ispolzovaniya korov chyorno-pyostroy porodyi $\mathrm{v}$ zavisimosti of krovnosti po golshtinam. Izvestiya Orenburgskogo gosudarstvennogo agrarnogo universiteta, 35(3), 113-114 (in Russian).

Grymak, Y., Skoromna, O., Stadnytska, O., Sobolev, O., Gutyj, B., Shalovylo, S., Hachak, Y., Grabovska, O., Bushueva, I., Denys, G., Hudyma, V., Pakholkiv, N., Jarochovich, I., Nahirniak, T., Pavliv, O., Farionik, T., \& Bratyuk, V. (2020). Influence of "Thireomagnile" and "Thyrioton" preparations on the antioxidant status of pregnant cows. Ukrainian Journal of Ecology, 10(1), 122-126. doi: 10.15421/2020_19.

Ibatullin, I. I., \& Holubiev, M. I. (2017). Effect of feeds containing different sources of manganese on certain carcass parameters of quail. Scientific Messenger of Lviv National University of Veterinary Medicine and Biotechnologies, 19(79), 13-16. doi: 10.15421/nvlvet7903.

Klitsenko, H. T., Kulyk, M. F., Kosenko, M. V., \& Lisovenko, V. T. (2001). Mineralne zhyvlennia tvaryn. K.: Svit (in Ukrainian).

Kropyvka, Y., \& Bomko, V. (2017). Efficiency of use of premixes on the basis of metal chelates in feeding cows in the first 100 days of lactation. Scientific Messenger of LNU of Veterinary Medicine and Biotechnologies. Series: Agricultural Sciences, 19(79), 154-158. URL: https://nvlvet.com.ua/ index.php/agriculture/article/view/2799 (in Ukrainian).

Kuznecov, S. G. (1992). Biologicheskaja dostupnost' mineral'nyh veshhestv dlja zhivotnyh. M. (in Russian).

Lonnerdal, B. (2000). Dietary factors influencing zinc absorbtion. J. Nutr., 130(5), 1378-1383. doi: 10.1093/jn/130.5.1378S.

Loretts, O. G. (2014). Vliyanie geneticheskih i ekologicheskih faktorov na produktivnoe dolgoletie. Agrarnyiy vestnik Urala, 9(127), 34-37 (in Russian).

Mahan, D. C. (1990). Mineral nutrition of the cow: a review. J. Anim. Sci., 68(2), 573-582. doi: $10.2527 / 1990.682573 x$.

Mazur, N. P., Fedorovych, V. V., Fedorovych, E. I., Fedorovych, O. V., Bodnar, P. V., Gutyj, B. V., Kuziv, M. I., Kuziv, N. M., Orikhivskyi, T. V., Grabovska, O. S., Denys, H. H., Stakhiv, N. P., Hudyma, V. Yu., \& Pakholkiv, N. I. (2020). Effect of morphological and 
biochemical blood composition on milk yield in Simmental breed cows of different production types. Ukrainian Journal of Ecology, 10(2), 61-67. doi: 10.15421/2020_110.

Roman, L., Sidashova, S., Popova, I., Stepanova, N., Chornyi, V., \& Gutyj, B. (2020). Clinical symptoms of damage to the lateral surface of the tibia of dairy cows of different phenotype in the conditions of industrial dairy production. Scientific Messenger of Lviv National University of Veterinary Medicine and Biotechnologies. Series: Veterinary sciences, 22(100), 3-10. doi: 10.32718/nvlvet10001.

Siratskyi, Y. Z., Ferents, L. B., Novak, I. V. (2008). Produktyvne vykorystannia ta yoho tryvalist $\mathrm{u}$ koriv ukrainskoi chorno-riaboi molochnoi porody. Visnyk instytutu tvarynnytstva tsentralnykh raioniv UAAN. Dnipropetrovsk, 4, 18-25 (in Ukrainian).
Stoljarchuk, P. Z., Petryshak, R. A. \& Naumjuk, O. S. (2000). Racional'na godivlja dijnyh koriv u litn'opasovyshhnyj period. Sil's'kyj gospodar, 7-8, 20-21 (in Ukrainian).

Sudakov, M. O., Bereza, V. I., \& Pidhurskyi, I. H. (1991). Mikroelementozy silskohospodarskykh tvaryn. K.: Urozhai (in Russian).

Usenko, V. V., \& Bayurov, L. I. (2014). Prodolzhitelnost hozyaystvennogo ispolzovaniya i prichinyi vyibrakovki korov iz osnovnogo stada uchhoza "Kuban" Kubanskogo GAU. Politematicheskiy setevoy elektronnyiy nauchnyiy zhurnal Kubanskogo gosudarstvennogo agrarnogo universiteta, 2(96), 160163 (in Russian).

Vinogradov, A. P. (1952). Mikroelementyi v zhizni rasteniy i zhivotnyih. M.: Selhozizdat (in Russian). 